\title{
Nitric oxide synthase blockade and body fluid volumes
}

A.M. Balaszczuk $1,2,3$, A. Tomat ${ }^{1}$, S. Bellucci ${ }^{1}$, A. Fellet ${ }^{1}$ and C. Arranz ${ }^{1,2,3}$

\author{
1Departamento de Fisiología, Facultad de Farmacia y Bioquímica, \\ Universidad de Buenos Aires, Buenos Aires, Argentina \\ ${ }^{2}$ Fundación Barceló, Buenos Aires, Argentina \\ 3IQ U IM EFA-PRO SIVAD CO NICET, Buenos Aires, Argentina
}

\section{Correspondence \\ A.M. Balaszczuk \\ Junín 956, Piso 7 \\ 1113 Buenos Aires \\ Argentina \\ Fax: + 54-11-4964-8280 \\ E-mail: abalasz@ huemul.ffyb.uba.ar \\ Research supported by Universidad de Buenos Aires, Fundación Barceló and IQ UIM EFA-PRO SIVAD CO NICET, Buenos Aires, Argentina.}

Received June 11, 2001 Accepted October 10, 2001

\section{Abstract}

The influence of chronic nitric oxide synthase inhibition with $\mathrm{N}^{\mathrm{G}_{-}}$ nitro-L-arginine methyl ester (L-NAME) on body fluid distribution was studied in male Wistar rats weighing 260-340 g. Extracellular, interstitial and intracellular spaces, as well as plasma volume were measured after a three-week treatment with L-NAME $(\approx 70 \mathrm{mg} / \mathrm{kg}$ per $24 \mathrm{~h}$ in drinking water). An increase in extracellular space (16.1 \pm 1.1 vs $13.7 \pm 0.6 \mathrm{ml} / 100 \mathrm{~g}$ in control group, $\mathrm{N}=12, \mathrm{P}<0.01)$, interstitial space $(14.0 \pm 0.9$ vs $9.7 \pm 0.6 \mathrm{ml} / 100 \mathrm{~g}$ in control group, $\mathrm{P}<0.001)$ and total water $(68.7 \pm 3.9$ vs $59.0 \pm 2.9 \mathrm{ml} / 100 \mathrm{~g}, \mathrm{P}<0.001)$ was observed in the L-NAME group $(\mathrm{N}=8)$. Plasma volume was lower in L-NAMEtreated rats $(2.8 \pm 0.2 \mathrm{ml} / 100 \mathrm{~g})$ than in the control group $(3.6 \pm 0.1 \mathrm{ml} /$ $100 \mathrm{~g}, \mathrm{P}<0.001)$. Blood volume was also lower in L-NAME-treated rats $(5.2 \pm 0.3 \mathrm{ml} / 100 \mathrm{~g})$ than in the control group $(7.2 \pm 0.3 \mathrm{ml} / 100 \mathrm{~g}$, $\mathrm{P}<0.001)$. The increase in total ratio of kidney wet weight to body weight in the L-NAME group $(903 \pm 31$ vs $773 \pm 45 \mathrm{mg} / 100 \mathrm{~g}$ in control group, $\mathrm{P}<0.01)$ but not in total kidney water suggests that this experimental hypertension occurs with an increase in renal mass. The fact that the heart weight to body weight ratio and the total heart water remained constant indicates that, despite the presence of high blood pressure, no modification in cardiac mass occurred. These data show that L-NAME-induced hypertension causes alterations in body fluid distribution and in renal mass.

Nitric oxide (NO) has an important role in the physiologic control of blood pressure. Alterations in NO synthesis may be involved in the pathogenesis of hypertension. There is evidence that the short-term and long-term in vivo administration of nitric oxide synthase (NOS) inhibitors such as $\mathrm{N}^{\mathrm{G}}$-nitro-L-arginine methyl ester (L-NAME) induces a doseand time-dependent increase in arterial blood pressure in conscious rats and adaptive changes in the functions of the kidney, heart and vessels (1). Three NOS isoforms (neu- ronal, inducible and endothelial) are expressed in the heart in a cell-specific manner (2) and in rat kidney, but it is unclear which NOS isoform(s) is/are responsible for the functional effects (3). The response to chronic NOS inhibition is likely to depend upon several factors, including the cellular source of NO, the amount released, the target tissue and interactions with neurohumoral factors (4). Recent investigations have shown that the chronic model of hypertension with LNAME is generally associated with an archi- 
tectural modification of cardiovascular tissues as well as with tubular and renal hemodynamic changes $(1,5)$. Moreover, it is likely that the modifications of renal and cardiovascular functions induced with L-NAME could lead to an abnormal control of body fluid volume (6). However, little information is available about the effect of chronic NOS inhibition on body volumes. On the basis of these considerations, we have studied the effect of chronic blockade of NO synthesis with L-NAME on body fluid distribution and on renal and cardiac tissue.

Long-term L-NAME treatment was performed on male Wistar rats weighing 260$340 \mathrm{~g}$, obtained from Facultad de Farmacia y Bioquímica breeding laboratories (Universidad de Buenos Aires, Argentina). Animals were housed in a temperature- and humiditycontrolled environment with automatic lighting in 12-h cycles and maintained on standard rat chow (Nutrimentos Purina, Buenos Aires, Argentina) and tap water ad libitum up to the day of the experiments. Animals were used in compliance with the Research Animals Use Guideline of the American Heart Association. A group of eight rats received L-NAME (Sigma, St. Louis, MO, USA) in the drinking water for three weeks, while 12 age-matched control rats received drinking tap water alone. The concentration of L-NAME was adjusted according to body weight and water intake, resulting in a daily intake of approximately $70 \mathrm{mg} / \mathrm{kg}$. At the end of treatment, systolic blood pressure was measured by the tail-cuff method using a Grass polygraph (model 79H, Grass Instruments Co., Quincy, MA, USA). All rats were anesthetized with urethane (Sigma), $1 \mathrm{~g} / \mathrm{kg}$ body weight, ip. Under aseptic conditions, both kidneys were removed through bilateral lumbar incisions. After performing a tracheotomy, the right jugular vein and the left carotid artery were catheterized for drug administration and later recovery of blood.

The extracellular space was determined as inulin space by injecting $0.7 \mathrm{ml}$ of a $13 \%$ inulin solution into the jugular vein, and an enzymatic method was used for the determination of plasma inulin (7). Plasma volume was evaluated according to the method of Wang (8) using Evans blue as indicator. The intracellular space was determined as the difference between total water and extracellular space. The interstitial space was obtained by subtracting plasma volume from inulin space. Total water was estimated as the difference between rat wet weight and dry weight. Dry weight was obtained by placing the dead rats and their organs in an oven at $100^{\circ} \mathrm{C}$ for three days (9). The hematocrit was measured by spinning in a microfuge the blood collected into microhematocrit tubes. Plasma albumin concentration was determined by a colorimetric method (bromocresol phthalein, Wienner Laboratories, Rosario, Argentina). Statistical differences between groups were evaluated by the Student $t$-test and a $5 \%$ probability level was used as a criterion for significance. Values are reported as means \pm SEM. The Prism software (Graph Pad Software) was used for statistical analysis.

Systolic blood pressure was significantly higher in animals after three weeks of LNAME treatment compared with control rats (161 \pm 7 vs $113 \pm 3 \mathrm{mmHg}, \mathrm{P}<0.001)$. Body weight of control rats was similar to that of the L-NAME group $(267 \pm 8$ and $273 \pm 9 \mathrm{~g}$, respectively). Furthermore, L-NAME treatment induced a significant increase in extracellular space, interstitial space and total water compared with control rats (Table 1). Plasma volume and blood volume were significantly lower in the L-NAME group, whereas no significant changes occurred in the hematocrit values (control: $51 \pm 1$, LNAME: $49 \pm 3 \%$ ). There was no significant difference in intracellular space between the control and L-NAME groups. The relationship between plasma volume and interstitial space decreased significantly in the L-NAME group compared with control rats $(0.21 \pm$ 0.02 to $0.40 \pm 0.04$, respectively, $\mathrm{P}<0.001$ ). 
Plasma albumin concentration did not change significantly after L-NAME administration (control: $2.25 \pm 0.12$, L-NAME: $1.90 \pm 0.14$ $\mathrm{g} / 100 \mathrm{ml})$.

The kidney weights of control and LNAME-treated groups are listed in Table 2. The total ratio of kidney wet weight to body weight showed a significant increase after treatment with L-NAME, and the kidney water/wet kidney ratio remained unchanged.

Finally, no effects on cardiac mass were observed after L-NAME treatment (LNAME: $347 \pm 11$, control: $362 \pm 7 \mathrm{mg} / 100 \mathrm{~g}$ ) or on heart water/wet heart ratio (L-NAME: $79.1 \pm 0.4$, control: $76.7 \pm 1.4 \mathrm{ml} / 100 \mathrm{~g}$ ).

The increase in extracellular space with the decrease in plasma volume observed in our experimental model indicates an increase of interstitial tissue compliance that permits the accumulation of fluids in this compartment. The increase in extracellular space, like total water, may be associated with a progressive antidiuretic and antinatriuretic effect induced by L-NAME administration, which can be only partially offset by the increase in blood pressure, promoting pressure natriuresis mechanisms $(10,11)$.

These body fluid changes in animals submitted to chronic L-NAME administration suggest that the hypertension observed could be, at least in part, volume dependent. In addition to the increase in vascular reactivity induced by NOS blocking, the extracellular fluid volume increase may provoke an increase of cardiac output which, after a variable period of time, may induce an increase in peripheral resistance by an autoregulation mechanism (12). However, the effects of LNAME administration on cardiac output remain unclear, and the different results reported in the literature may be due to differences in the experimental designs $(10,13,14)$.

Furthermore, we observed that chronic administration of L-NAME caused a slight nonsignificant decrease in plasma albumin. This result agrees with published findings demonstrating that chronic NOS inhibition causes accelerated proteinuria, leading to a plasma protein decrease $(6,11)$. This may result in an increase in the interstitial space probably due to fluid efflux from the plasma space. We have also observed that the plasma volume contraction did not cause a significant change in hematocrit; probably the amount of volume involved was too small to cause any alteration of this parameter. The changes in body volumes induced by LNAME administration were not reflected in body weight.

On the other hand, the total ratio of kidney wet weight to body weight increased significantly after L-NAME treatment, whereas the kidney water/wet kidney weight ratio remained constant, indicating an increase of renal mass. Numerous studies have demonstrated that chronic NOS inhibition in experimental models and in humans may

Table 1. Body fluid distribution in response to L-NAME.

\begin{tabular}{lcc}
\hline $\begin{array}{l}\text { Parameter }(\mathrm{ml} / 100 \mathrm{~g} \\
\text { body weight })\end{array}$ & $\begin{array}{c}\text { Control group } \\
(\mathrm{N}=12)\end{array}$ & $\begin{array}{c}\text { L-NAME group } \\
(\mathrm{N}=8)\end{array}$ \\
\hline $\mathrm{H}_{2} \mathrm{Ot}$ & $59.0 \pm 2.9$ & $68.7 \pm 3.9^{* *}$ \\
$\mathrm{H}_{2} \mathrm{Oe}$ & $13.7 \pm 0.6$ & $16.1 \pm 1.1^{*}$ \\
$\mathrm{PV}$ & $3.6 \pm 0.1$ & $2.8 \pm 0.2^{* *}$ \\
$\mathrm{BV}$ & $7.2 \pm 0.3$ & $5.2 \pm 0.3^{* *}$ \\
$\mathrm{H}_{2} \mathrm{Ois}$ & $9.7 \pm 0.6$ & $14.0 \pm 0.9^{* *}$ \\
$\mathrm{H}_{2} \mathrm{Oin}$ & $46.7 \pm 2.9$ & $49.0 \pm 3.8$
\end{tabular}

Data are reported as means \pm SEM. N: number of rats; $\mathrm{H}_{2} \mathrm{Ot}$ : total body water; $\mathrm{H}_{2} \mathrm{Oe}$ : extracellular space; $\mathrm{PV}$ : plasma volume; $\mathrm{BV}$ : blood volume; $\mathrm{H}_{2} \mathrm{Ois}$ : interstitial space; $\mathrm{H}_{2} \mathrm{Oin}$ : intracellular space. $* \mathrm{P}<0.01$ compared to control (Student t-test).

$* * \mathrm{P}<0.001$ compared to control (Student t-test).

Table 2. Kidney weight and fluid distribution in response to L-NAME.

\begin{tabular}{lcc} 
Group & $\begin{array}{c}\text { WW/wet body weight } \\
(\mathrm{mg} / 100 \mathrm{~g})\end{array}$ & $\begin{array}{c}\text { KW/wet kidney } \\
(\mathrm{ml} / 100 \mathrm{~g})\end{array}$ \\
\hline Control $(\mathrm{N}=12)$ & $773 \pm 45$ & $75.9 \pm 1.6$ \\
L-NAME $(\mathrm{N}=8)$ & $903 \pm 31^{*}$ & $76.6 \pm 0.6$
\end{tabular}

Data are reported as means \pm SEM. N: number of rats; WW: wet weight; KW: kidney water.

$* \mathrm{P}<0.05$ compared to control (Student t-test). 
produce deleterious effects on renal tissues and function, leading to abnormalities in renal response $(11,15,16)$, whereas others have found an increase in protein synthesis in the kidney (17). These findings could explain, at least in part, the hypertrophy observed in our experimental model.

It was reported that chronic L-NAME treatment causes cardiovascular metabolic alterations and myocardial remodeling (18). These changes would be expected to induce cardiac hypertrophy as a compensatory response that depends on the duration and magnitude of the rise in blood pressure. However, in our experimental design the chronic L-NAME treatment induced hypertension without changes in cardiac mass, in agreement with other studies, supporting the hypothesis that the adaptation to pressure overload may occur without changes in cardiac mass (19).

The results of the present study suggest that the chronic rise in arterial blood pressure induced by long-term blockade of NO synthesis involves an abnormal body fluid distribution in addition to the increase in vascular reactivity already described. The increase in renal mass could be a consequence of NO pathway inhibition and/or the activation of other systems in response to the altered electrolyte and water metabolism.

\section{References}

1. Bartunek J, Weinberg EO, Tajima M, Rohrbach S, Katz SE, Douglas PS \& Lorell BH (2000). Chronic N(G)-nitro-L-arginine methyl ester-induced hypertension: novel molecular adaptation to systolic load in absence of hypertrophy. Circulation, 101: 423-429.

2. Balligand J L, Kobzik L, Han X, Kaye DM, Belhassen L, O'Hara D, Kelly RA, Smith TW \& Michel T (1995). Nitric oxide-dependent parasympathetic signaling is due to activation of constitutive endothelial (type III) nitric oxide synthase in cardiac myocytes. J oumal of Biological Chemistry, 270: 14582-14586.

3. Govers R \& Rabelink TJ (2001). Cellular regulation of endothelial nitric oxide synthase. American J ournal of Physiology, 280: F193-F206.

4. Shah AM \& MacCarthy PA (2000). Paracrine and autocrine effect of nitric oxide on myocardial function. Pharmacology and Therapeutics, 86: 49-86.

5. Linas SL \& Repine J E (1999). Endothelial cells regulate proximal tubule epithelial cell sodium transport. Kidney International, 55: 1251-1258.

6. Yamada S, Sassaki AL, Fujihara C, Malheiros DM, De Nucci $G \&$ Zatz $R$ (1996). Effect of salt intake and inhibitor dose on arterial hypertension and renal injury induced by chronic nitric oxide blockade. Hypertension, 27: 1165-1172.

7. Gabel R, Ranaei RA \& Kivlighn SD (1996).
A new method of measuring renal function in conscious rats without the use of radioisotopes. J ournal of Pharmacological and Toxicological Methods, 36: 189-197.

8. Wang L (1959). Plasma volume, cell volume, total blood volume and $F$ cells factor in the normal and splenectomized Sherman rat. American J ournal of Physiology, 196: 188-192.

9. Miller DS \& Render AE (1955). The determination of the net protein utilization of proteins by a shortened method. British J ournal of Nutrition, 9: 382-388.

10. Cases A, Haas J, Burnett J C \& Romero J C (2001). Hemodynamic and renal effects of acute and progressive nitric oxide synthesis inhibition in anesthetized dogs. American J ournal of Physiology, 280: R143-R148.

11. Qiu C, Muchant D, Beierwaltes W, Racusen L \& Baylis C (1998). Evolution of chronic nitric oxide inhibition hypertension: Relationship to renal function. Hypertension, 31 (Part 1): 21-26.

12. Guyton AC (1977). Personal views on mechanisms of hypertension. In: Genest KK (Editor), Hypertension. McGraw-Hill, Maidenhead, NY, 556-575.

13. Doursout MF, Hartley CJ \& Chelly JE (2001). Comparison of cardiac and regional hemodynamic responses to $\mathrm{N}$ methyl-L-arginine and aminoguanidine infusions in conscious pigs. J ournal of Cardiovascular Pharmacology, 37: 349-358.
14. Faro R, Tanus-Santos J E, Zappellini A, Antunez E \& Denucci G (1999). The role of heart rate in the modulation of the decreased cardiac output induced by acute nitric oxide synthesis inhibition in anaesthetized dogs. J ournal of Autonomic Pharmacology, 19: 257-262.

15. Granger JP \& Alexander BT (2000). Abnormal pressure-natriuresis in hypertension: role of nitric oxide. Acta Physiologica Scandinavica, 168: 161-168.

16. Xiao S, Wagner L, Schmidt RJ \& Baylis C (2001). Circulating endothelial nitric oxide synthase inhibitory in some patients with chronic renal disease. Kidney International, 59: 1466-1472.

17. Bernátová $I$, Pecháñová $O \&$ Simko $F$ (1999). Effect of captopril in L-NAME-induced hypertension on the rat myocardium, aorta, brain and kidney. Experimental Physiology, 84: 1095-1105.

18. Tribulová L, Oknuhlicová I, Bernátová I \& Pecháñová O (2000). Chronic disturbances in NO production result in histochemical and subcellular alterations of the rat heart. Physiological Research, 49: 77-88.

19. Arnal J, El Amrani A, Chatellier G, Ménard J \& Michel J (1993). Cardiac weight in hypertension induced by nitric oxide synthase blockade. Hypertension, 22: 380387. 